\title{
Paleolimnological inferences based on Oligocene ostracods (Crustacea: Ostracoda) from Tremembé Formation, Southeast Brazil
}

\author{
CRISTIANINI T. BERGUE ${ }^{1}$, MARIA DA SAUDADE A.S. MARANHÃ ${ }^{2}$ and GERSON FAUTH ${ }^{1}$ \\ ${ }^{1}$ Universidade do Vale do Rio dos Sinos, Instituto Tecnológico de Micropaleontologia - \\ itt Fossil, Av. Unisinos, 950, 93022-000 São Leopoldo, RS, Brasil \\ ${ }^{2}$ Instituto Geológico do Estado de São Paulo, Av. Miguel Stéfano, 3900, 043301-903 São Paulo, SP, Brasil
}

Manuscript received on July 14, 2014; accepted for publication on November 28, 2014

\begin{abstract}
Non-marine Oligocene ostracods from Tremembé Formation (Taubaté Basin, Southeast Brazil) are studied for the first time. The study reveals rich assemblages which are probably composed of many new taxa, two of which are described here. The sixteen ostracod species registered are classified in the genera Cypretta Vávra, Strandesia Stuhlmann, Potamocypris Brady, Heterocypris Claus, Eucypris Vávra, Herpetocypris Brady and Norman, Cytheridella Daday and Limnocythere Brady. Two new species of the latter are herein proposed: L. mandubi sp. nov. and L. katu sp. nov. The succession of ostracod assemblages along the studied core changes conspicuously in composition, abundance and preservation, and are characterized by the following associations: Herpetocypris-Cytheridella (lower), Limnocythere-Cypretta (middle) and Potamocypris-Heterocypris (upper). It is assumed that these associations represent different ecological phases of the paleolake Taubaté which is in accordance to previous stratigraphic and paleontological studies in the basin. The results from this pioneering taxonomic and paleoecological study on ostracods from Tremembé Formation reinforce the potential of these fossils for paleolimnological researches in Brazilian Cenozoic deposits.
\end{abstract}

Key words: Ostracods, paleolimnology, taxonomy, Tremembé Formation.

\section{INTRODUCTION}

The study of fossil non-marine ostracods in Brazil began in a wide research project set out by Pinto and Sanguinetti (1958) aiming at improving the knowledge and comparative analysis of Early Cretaceous assemblages. Although the studies went deep in basins with economic potential, the same did not occur in younger (i.e., Cenozoic) deposits, which data now available are scarcer and mostly restricted to the Neogene mixohaline assemblages

Correspondence to: Cristianini Trescastro Bergue

E-mail: ctbergue@gmail.com of Northern region (e.g. Purper 1979, Ramos 2006, Gross et al. 2013).

The Oligocene non-marine deposits of Tremembé Formation (Taubaté Basin) preserve a vast array of fossils, such as mammals, birds, fishes and plants (Mezzalira 1989). In spite of the abundance of ostracods, there are no published studies describing the assemblages and their paleoecology. Therefore, the main objectives of this work are to study the taxonomy of ostracods, to interpret the paleoecology of the assemblages and the taphonomy of some specimens. 
The Taubaté Basin, which originated from a tectonic lake, lies between the Serra do Mar and the Serra da Mantiqueira mountain ranges in the state of São Paulo, Southeast Brazil (Fig. 1). It is positioned in the NE-SW direction, as part of the Southeast Brazilian Continental Rift (Riccomini et al. 2004), where a step fault system generated a half-graben. The very fossiliferous Tremembé Formation is composed predominantly by lacustrine facies reaching, at its depocenter, $500 \mathrm{~m}$ thickness.

The ZooBank Life Science Identifier (LSID) of this publication is: urn.lsid:zoobank. org:pub:013C 7493 - 90 B 2 - 441 A - A A 3 F 601D4DF402EC.

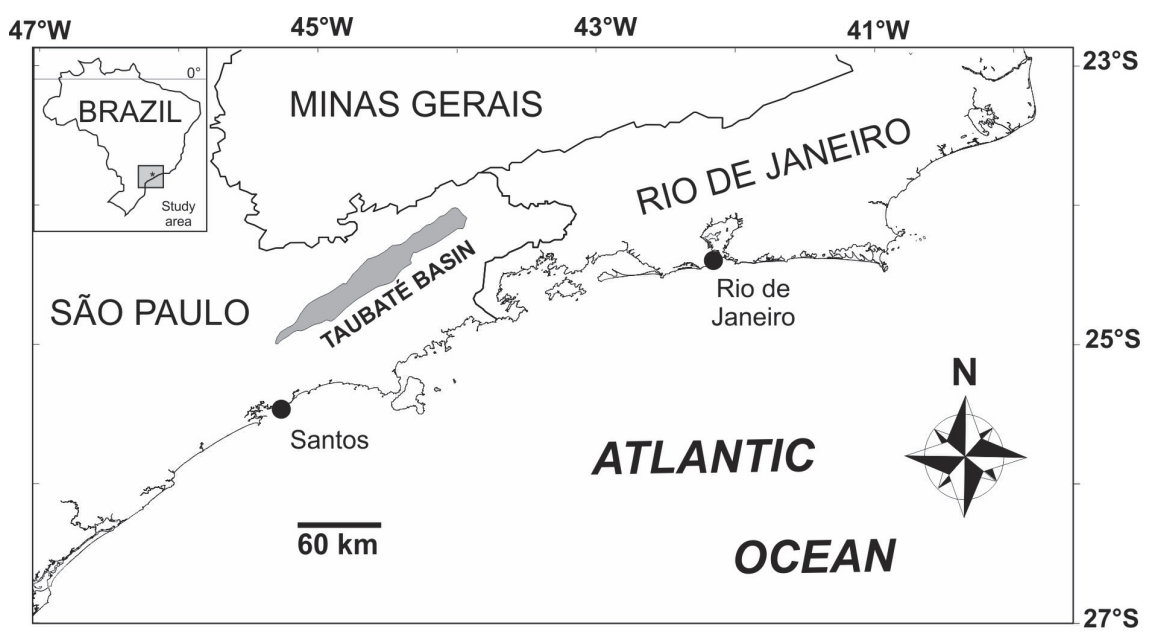

Figure 1 - Map of location of the Taubaté Basin.

\section{MATERIALS AND METHODS}

The 14 samples $(500 \mathrm{~g})$ studied here are from a $115 \mathrm{~m}$ long core, drilled at the coordinates $45^{\circ} 30^{\prime} 34^{\prime \prime} \mathrm{W} / 23^{\circ} 01^{\prime} 49^{\prime \prime} \mathrm{S}$ in Taubaté town. The sampling intervals were selected according to their lithologic composition, which mostly correspond to shales, argillites and sandstones (Fig. 2). Samples were disaggregated with hydrogen peroxide and washed through sieves. Ostracods were picked from the residue of the 0.25 and $0.18 \mathrm{~mm}$ mesh sieves. All specimens occurring in the samples were picked and mounted in paleontological slides for study. Specimens representative of each taxon were selected for SEM imaging.

\section{SYSTEMATIC PALEONTOLOGY}

Based mainly on Martens and Savatenalinton (2011) and Karanovic (2012), the 16 species registered were classified into eight genera and two families: Cyprididae (nine spp.) and Limnocytheridae (six spp.). The abun- dance and occurrence of each taxon are presented in Table I. All the specimens here illustrated are held at the Museu de História Geológica do Rio Grande do Sul, of Universidade do Vale do Rio dos Sinos, Brazil, under the curatorial numbers ULVG 11506 to 11528 and 11575. Morphological abbreviations: $\mathrm{C}$, carapace; $\mathrm{CC}$, carapace cast; RV, right valve; $\mathrm{LV}$, left valve; 1 , length; h, height; w, width.

Suborder Cypridocopina Baird 1845

Superfamily Cypridoidea Baird 1845

Family Cyprididae Baird 1845

Genus Cypretta Vávra 1895

Type species: Cypridopsis (Cypretta) tenuicauda Vávra 1895

Cypretta sp.

Figs. 3.1-3

Figured specimen: ULVG 11506, C, 1: $0.72 \mathrm{~mm}$; h: $0.52 \mathrm{~mm}$; w: $0.54 \mathrm{~mm}$.

Origin: sample $73 \mathrm{~m}$. 


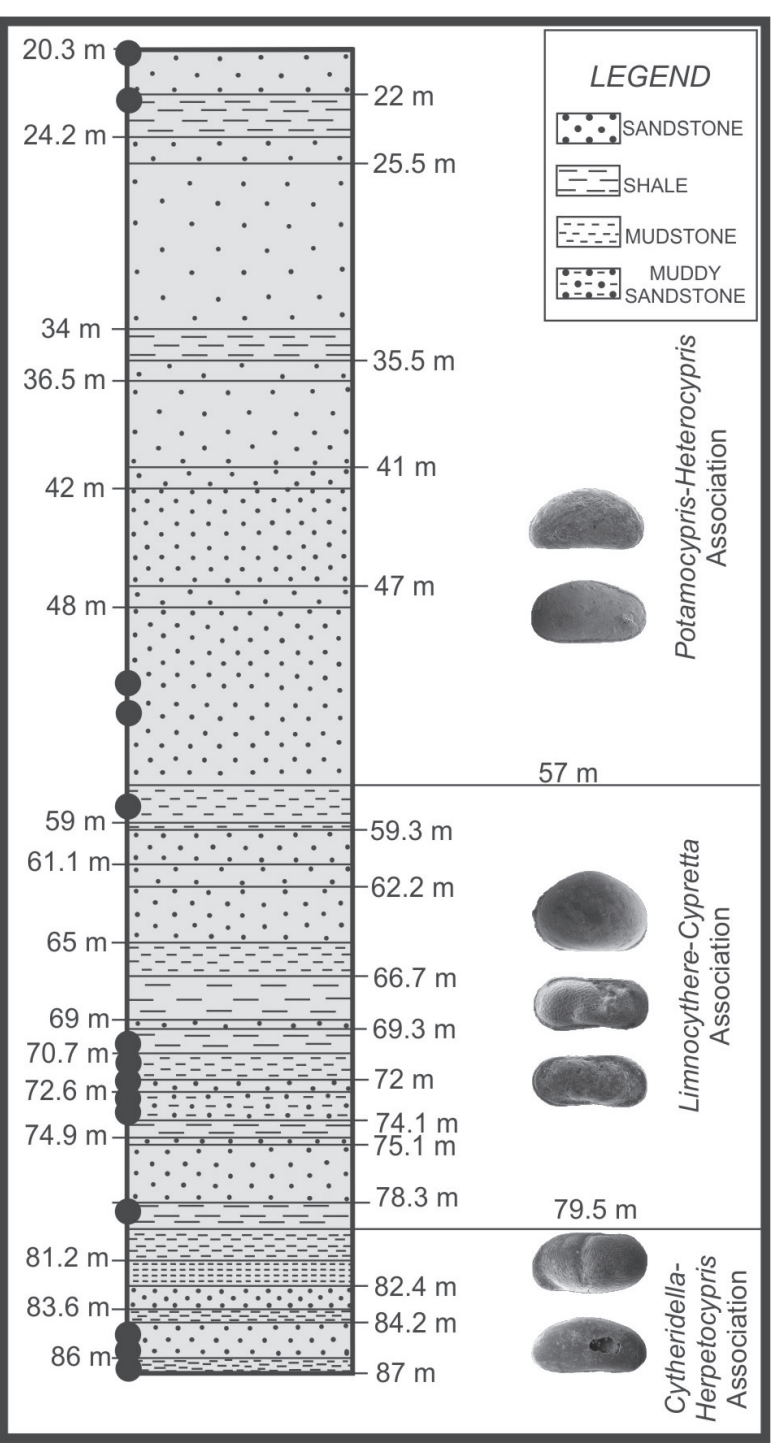

Figure 2 - Lithologic profile of the studied core and occurrence of the characteristic ostracod associations. Black dots indicate the sampling points.

Remarks: According to Cohuo-Durán et al. (2013), some species of this genus have valve reversal (e.g. Cypretta vivacis Würdig and Pinto, 1993). In the species studied here, however, the LV overlaps the RV.

Subfamily Cypricercinae McKenzie 1971

Genus Strandesia Stuhlmann 1888

Type species: Cypris mercatorum Vávra 1895

Strandesia sp.

Figs. 3.4-5
Figured specimen: ULVG 11507, C, 1: $0.94 \mathrm{~mm}$; h: $0.44 \mathrm{~mm}$; w: $0.36 \mathrm{~mm}$.

Origin: sample $22.4 \mathrm{~m}$.

Remarks: Though Strandesia is usually reminded by the dorsal alae on the right valve such as in Strandesia bicuspis Claus 1892, Karanovic (2005) comments on its absence in a group of species. The taxon here illustrated is similar to $S$. purpurascens (Brady 1886) in the outline and slopping dorsal margin whose highest part is immediately after the anterior cardinal angle.

Subfamily Cypridopsinae Kaufmann 1900

Genus Potamocypris Brady 1870

Type-species: Bairdia fulva Brady 1868

Potamocypris sp.

Figs. 3.6-7

Figured specimen: ULVG 11508, C, 1: $0.64 \mathrm{~mm}$, h: $0.34 \mathrm{~mm}$, w: $0.24 \mathrm{~mm}$.

Origin: sample $22.4 \mathrm{~m}$.

Remarks: Potamocypris sp. is very abundant in the material studied, but the specimens are mostly crushed, possibly due to the fragile composition of the carapaces. The species is classified as Potamocypris based on the small size, the outline and the RV overlapping the LV ventrally.

Subfamily Cyprinotinae Bronshtein 1947

Genus Heterocypris Claus 1892

Type species: Cypris incongruens Ramdohr 1808

Heterocypris sp. 1

Figs. 3.8-11

Figured specimens: ULVG 11509, RV, 1: $1.1 \mathrm{~mm}$; h: $0.6 \mathrm{~mm}$; ULVG 11510, C, l: $1.1 \mathrm{~mm}$; h: $\sim 0.5 \mathrm{~mm}$.

Origin: sample $73 \mathrm{~m}$.

Remarks: A small nodule in the ventro-lateral part of the RV has been noticed in one specimen (ULVG 11510). The absence of this feature in other specimens from the same sample demonstrates its probable pathologic origin. This species is identified as Heterocypris due to the presence of a row of small tubercles in the posterior ventral margin (Fig. 3.10). 
TABLE I

Occurrence and abundance of the taxa studied along the core.

\begin{tabular}{|c|c|c|c|c|c|c|c|c|c|c|c|c|c|c|c|c|}
\hline $\begin{array}{l}\text { DEPTH } \\
\text { (m) }\end{array}$ & 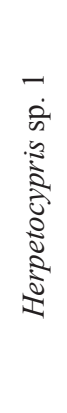 & 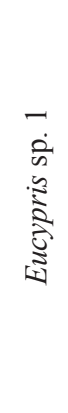 & 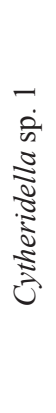 & 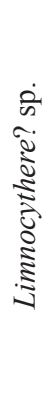 & 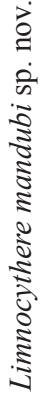 & 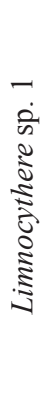 & 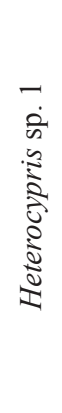 & 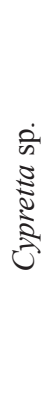 & 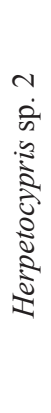 & 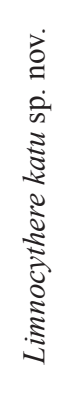 & 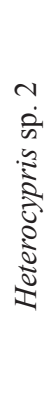 & 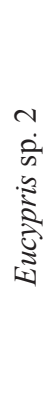 & 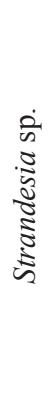 & 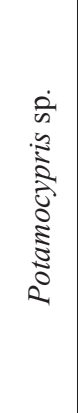 & 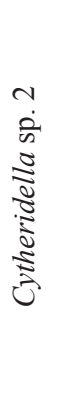 & 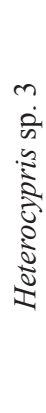 \\
\hline 22.4 & & & & & & & & & & & & & 1 & $>200$ & 4 & 12 \\
\hline 51.65 & & & & & & & & & & & & 1 & & & & \\
\hline 58.4-59 & & & & & & & & & & & 49 & & & & & \\
\hline $70-70.1$ & & 46 & & & & & & & & 119 & & & & & & \\
\hline 71.5 & & 176 & & & & & & & & 104 & & & & & & \\
\hline 72 & 12 & & & & & & 19 & 5 & & & & & & & & \\
\hline 73 & 24 & & & & 6 & & 68 & 3 & 4 & & & & & & & \\
\hline 73.2 & 42 & & & & & & 106 & & & & & & & & & \\
\hline 78.5 & & 28 & & & & 3 & & & & & & & & & & \\
\hline 85 & & & 6 & & & & & & & & & & & & & \\
\hline $85.25-85.3$ & 152 & & 5 & 3 & & & & & & & & & & & & \\
\hline 87 & 19 & & 2 & & & & & & & & & & & & & \\
\hline ABUNDANCE & 249 & 252 & 13 & 3 & 6 & 3 & 193 & 8 & 4 & 223 & 49 & 1 & 1 & $>200$ & 4 & 12 \\
\hline
\end{tabular}

Heterocypris sp. 2

Figs. 3.12-14

Figured specimen: ULVG 11511, 1: $1.26 \mathrm{~mm}$; h: $0.66 \mathrm{~mm}$; w: $0.54 \mathrm{~mm}$.

Origin: sample $58.4-59 \mathrm{~m}$.

Remarks: This species is similar to H. incongruens (Ramdohr 1808) registered by Purper and WürdigMaciel (1974) in Tramandaí, state of Rio Grande do Sul, Brazil. Heterocypris sp. 2, however, is slightly smaller and does not present the valve asymmetry of $H$. incongruens.

\section{Heterocypris sp. 3}

Figs. 3.15-18

Figured specimens: ULVG 11512, C, 1: $0.94 \mathrm{~mm}$; h: $0.5 \mathrm{~mm}$; w: $0.36 \mathrm{~mm}$. ULVG 11513, LV, 1: 0.94 $\mathrm{mm}$; h: $0.5 \mathrm{~mm}$.
Origin: sample $22.4 \mathrm{~m}$.

Remarks: This species differs from Heterocypris sp. 1 and Heterocypris sp. 2 for its more subrectangular outline in lateral view. It is also smaller than the two aforementioned species.

Subfamily Eucypridinae Bronshtein 1947

Genus Eucypris Vávra 1891

Type species: Monoculus virens Jurine 1820

\section{Eucypris sp. 1}

Figs. 4.1-3

Figured specimens: ULVG 11514, C, 1: $1.1 \mathrm{~mm}$; h: $0.56 \mathrm{~mm}$; w: $0.46 \mathrm{~mm}$.

Origin: sample $71.5 \mathrm{~m}$.

Remarks: A very similar species has been registered by Sheppard and Bate (1980) in Solimões Formation (Peru), as Pontocypris? sp. The species is classified as Eucypris based on its outline and size. 


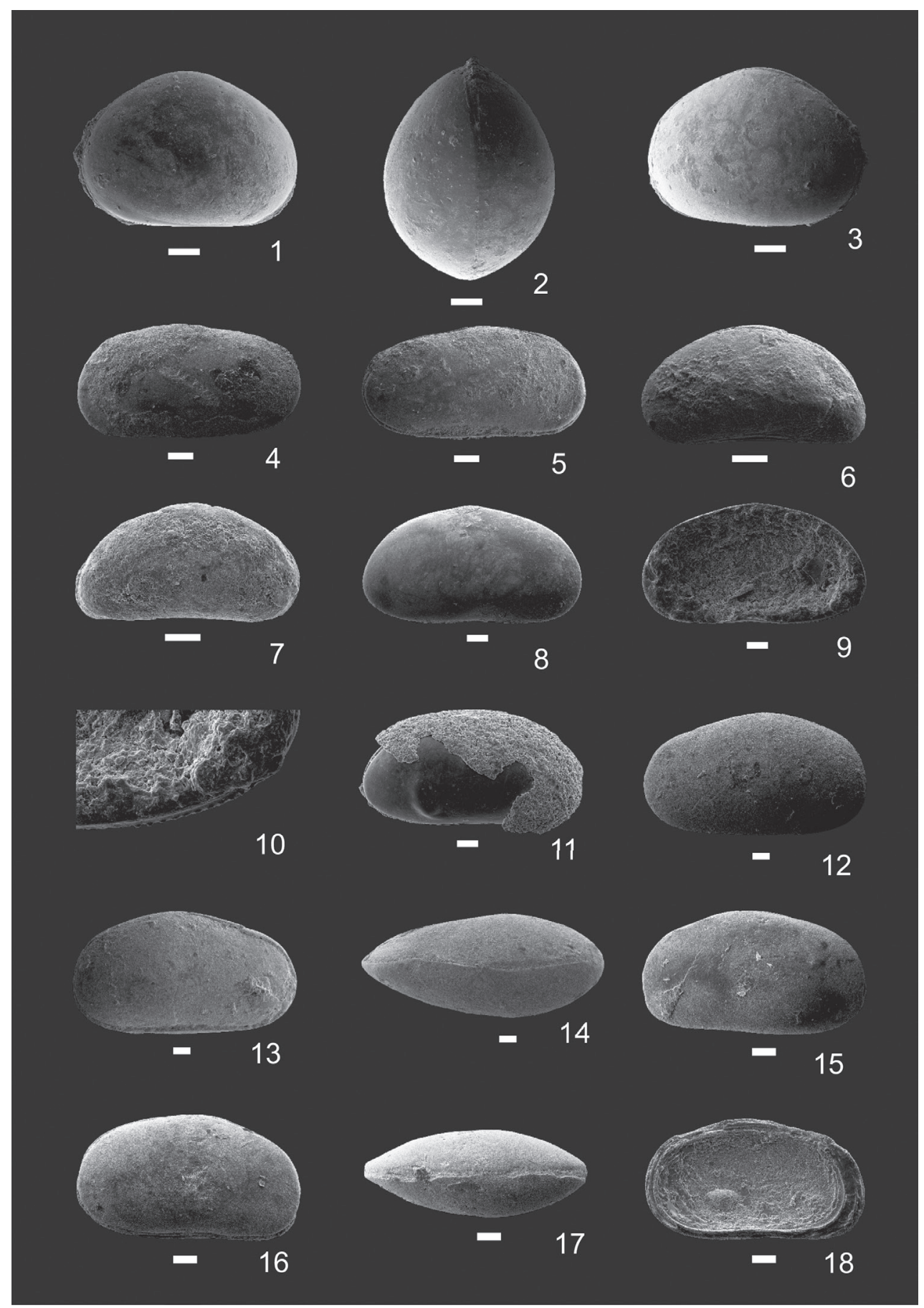

Figure 3 - 1-3 Cypretta sp. (ULVG 11506, C) 1. Left lateral view; 2. Dorsal view; 3. Right lateral view; 4-5 Strandesia sp. (ULVG 11507, C) 4. Left lateral view; 5. Right lateral view; 6-7 Potamocypris sp. (ULVG 11508, C) 6. Left lateral view; 7. Right lateral view; 8-11 Heterocypris sp. 1 (ULVG 11509, RV and ULVG 11510, C) 8. RV external view; 9. RV internal view; 10. Detail of the posteroventral region of RV; 11. C with posteroventral nodule; 12-14 Heterocypris sp. 2 (ULVG 11511, C) 12. Left lateral view; 13. Right lateral view; 14. Dorsal view; 15-18 Heterocypris sp. 3 (ULVG 11512, C and ULVG 11513, LV), 15. C left lateral view; 16. C right lateral view; 17. C dorsal view; 18. Left valves cup-in-cup. Scale= $=100 \mu$. 
Eucypris sp. 2

Figs. 4.4-6

Figured specimen: ULVG 11515, 1: $1.08 \mathrm{~mm}$; h: $0.6 \mathrm{~mm}$; w: $0.5 \mathrm{~mm}$.

Origin: sample $51.65 \mathrm{~m}$.

Remarks: Eucypris sp. 2 differs from Eucypris sp. 1 in the outline of carapace in lateral view and in the length/height ratio.

Subfamily Herpetocypridinae Kaufmann 1900

Genus Herpetocypris Brady and Norman 1889

Type species: Cypris reptans Baird 1835

Herpetocypris sp. 1

Figs. 4.7-12

Figured specimens: ULVG 11516, male C, 1: $1.62 \mathrm{~mm}$, h: $0.74 \mathrm{~mm}$; ULVG 11517, female C, 1 : $1.6 \mathrm{~mm}$; h: $0.74 \mathrm{~mm}$; w: $0.56 \mathrm{~mm}$.

Origin: sample $73 \mathrm{~m}$.

Remarks: Males and females are distinguished by the outline at the posterodorsal region. The width of the male specimen was not measured due its poor preservation. The species is classified as Herpetocypris based on the outline of the elongated and laterally compressed carapace.

\section{Herpetocypris sp. 2}

Figs. 4.13-15

Figured specimen: ULVG 11518, male C, 1: 1.2 mm; h: $0.52 \mathrm{~mm}$; w: $0.38 \mathrm{~mm}$.

Origin: sample $73 \mathrm{~m}$.

Remarks: Herpetocypris sp. 2 differs from Herpetocypris sp. 1 mainly in the dorsal margin and in the outline of the anterior margin. It is similar to a living species of Herpetocypris registered by Laprida et al. (2006) in Argentina.

Suborder Cytherocopina Gründel 1967

Superfamily Cytheroidea Baird 1850

Family Limnocytheridae Klie 1938

Genus Limnocythere Brady 1868

Type species: Cythere inopinata Baird 1843
Limnocythere mandubi sp. nov.

Figs. 4.16-18; Fig. 5.1

ZooBank Life Science Identifier (LSID) - urn. 1sid:zoobank.org:act:C35EOF6C-F703-4C84A41C-26E7D1A2B60D

Derivatio nominis: In reference to the outline of the carapace in ventral view. The word "mandubi" in the Brazilian native language Tupi means peanut.

Holotype: ULVG 11519, C, 1: 0.7 mm; h: 0.32 mm; $\mathrm{w}: 0.26 \mathrm{~mm}$.

Paratypes: ULVG 11520, C, 1: $0.68 \mathrm{~mm}$; h: 0.32 $\mathrm{mm}$; w: $0.28 \mathrm{~mm}$. ULVG 11521, RV, 1: $0.68 \mathrm{~mm}$; h: $0.32 \mathrm{~mm}$.

Type locality: Taubaté town (4530'34'W/ $23^{\circ} 01^{\prime} 49$ 'S), state of São Paulo, Brazil. Tremenbé Formation, sample $73 \mathrm{~m}$.

Age: Oligocene.

Material: six specimens.

Diagnosis: Carapace subrectangular and reticulated with an oblique ventrolateral inflation reaching up to the middle of the carapace.

Description: Carapace subrectangular, elongated and with both anterior and posterior margins symmetrically rounded. LV slightly larger than RV. Dorsal margin slightly sinuous with deepest portion at the middle; ventral margin obscured in the anterior middle by the strong oblique ventrolateral inflation which is developed in the posterior third. Anterior region compressed. Surface reticulated except in the middle/anterodorsal part, marked by the muscle insertions typical of many species of the genus. Maximum height at the posterior third. Internal features not seen. Sexual dimorphism not observed.

Remarks: Limnocythere mandubi sp. nov. is amazingly similar to a species of another limnocytherid genus: Ovambocythere milani Martens 1989. They differ in the reticulation pattern, which is more subtle in the species here proposed. O. milani also has a well-developed ventrolateral ridge. 


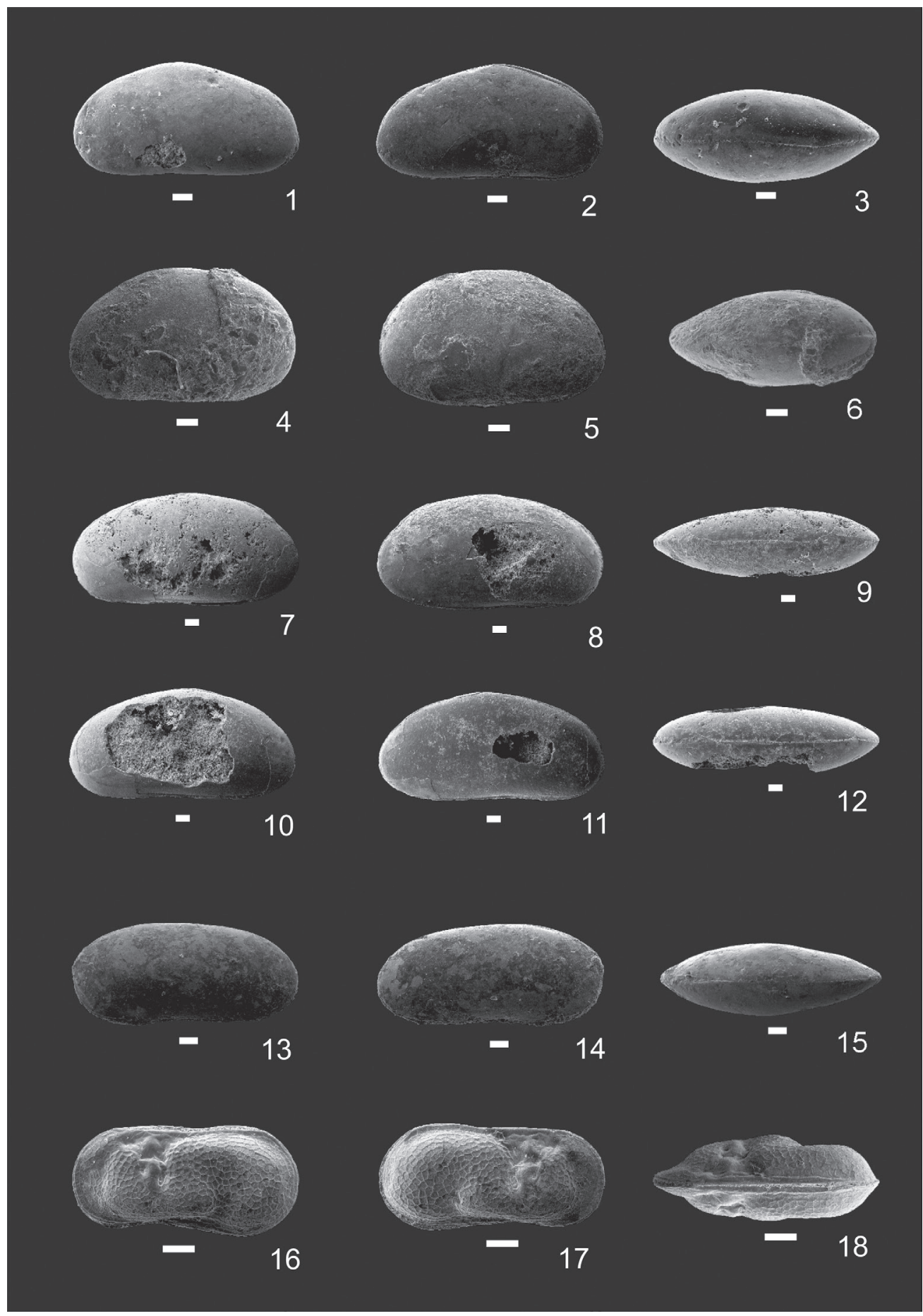

Figure 4 - 1-3 Eucypris sp. 1 (ULVG 11514, C), 1. Left lateral view; 2. Right lateral view; 3. Dorsal view; 4-6 Eucypris sp. 2 (ULVG 11515, C), 4. Left lateral view; 5. Right lateral view; 6. Dorsal view; 7-12 Herpetocypris sp. 1 (ULVG 11517, female C), 7. Left lateral view; 8. Right lateral view; 9. Dorsal view; 10. Left lateral view (ULVG 11516, male C); 11. Right lateral view; 12. Dorsal view; 13-15 Herpetocypris sp. 2 (ULVG 11518, C), 13. Left lateral view; 14. Right lateral view; 15. Dorsal view. 16-18 Limnocythere mandubi sp. nov. (ULVG 11519, C), 16. Left lateral view; 17. Right lateral view; 18. Dorsal view. Scale $=100 \mu$. 


\section{Limnocythere katu sp. nov.}

Figs. 5.2-9

ZooBank Life Science Identifier (LSID) - urn. 1sid:zoobank.org:act54A94539-CF83-41FD-989E4FDA85A18273.

Derivatio nominis: In allusion to the smooth surface of the carapace. The word "katu" in the Brazilian native language Tupi means clear.

Holotype: ULVG 11522, female C, 1: $0.76 \mathrm{~mm}$; h: $0.36 \mathrm{~mm}$; w: $0.26 \mathrm{~mm}$.

Paratypes: ULVG 11523, male C, 1: $0.76 \mathrm{~mm}$; h: $0.34 \mathrm{~mm}$; w: $0.26 \mathrm{~mm}$; ULVG 11524, female A-1 C, 1: $0.7 \mathrm{~mm}$, h: $0.33 \mathrm{~mm}, \mathrm{w}: 0.26 \mathrm{~mm}$; ULVG 11575, male A-1 RV, 1: $0.7 \mathrm{~mm}$, h: $0.32 \mathrm{~mm}$.

Type locality: Taubaté town $\left(45^{\circ} 30^{\prime} 34^{\prime \prime} \mathrm{W} /\right.$ $23^{\circ} 01$ '49”'S), state of São Paulo, Brazil. Tremenbé Formation, sample $71.5 \mathrm{~m}$.

Age: Oligocene.

Material: 223 specimens.

Diagnosis: Carapace subretangular, smooth and with the middle portion of ventral margin strongly concave.

Description: Carapace elongated, subrectangular. Anterior margin almost symmetrically rounded. Posterior margin symmetrically rounded and marked by shallow sulcus. Dorsal margin almost straight with slight depression in the middle; ventral margin concave in the middle portion. Surface smooth, marked only by the sulci. Median sulci almost straight and reaching the middle of carapace. Internal features not seen. Sexual dimorphism conspicuous: males with ventrolateral bulge and more narrow in the posterior of carapace.

Remarks: Limnocythere katu sp. nov. differs from L. mandubi sp. nov. in the outline, size, and absence of reticulation.

Limnocythere sp. 1

Figs. 5.10-11

Figured specimen: ULVG 11525, RV, 1: 0.68 mm; h: $0.3 \mathrm{~mm}$.
Origin: sample $78.5 \mathrm{~m}$.

Remarks: Limnocythere sp. 1 has the ventral margin less concave and the sulci less developed than Limnocythere katu sp. nov.

Limnocythere? sp.

Figs. 5.12-13

Figured specimen: ULVG 11526, CC, 1: $0.76 \mathrm{~mm}$; h: $0.34 \mathrm{~mm}$, w: $0.24 \mathrm{~mm}$.

Origin: sample $85.25-85.30 \mathrm{~m}$.

Remarks: Though similar to L. katu sp. nov. it possibly represents a different species of Limnocythere due to the size, the concavity of the dorsal margin and the inflated posterior region.

Subfamily Timiriaseviinae Mandelstam 1960

Genus Cytheridella Daday 1905

Type species: Cytheridella ilosvayi Daday 1905

Cytheridella sp. 1

Figs. 5.14-16

Figured specimen: ULVG 11527, female LV, 1: $1.02 \mathrm{~mm}$; h: $0.54 \mathrm{~mm}$.

Origin: sample $87 \mathrm{~m}$.

Remarks: The genus Cytheridella was described in Paraguay (South America) and considered, over a period of time, as an exclusively living limnocytherid (Pinto and Sanguinetti 1962). In the last few decades, however, its fossil record in South America has been expanded to the Neogene [Gross et al. 2013 (Miocene), Ramos 2006 (Miocene), Bold 1986 (Pliocene), Sheppard and Bate 1980 (Plio-Pleistocene), Purper 1979 (Miocene?)]. A revision by Gross et al. (2013), however, revealed that all these occurrences referred to C. boldi Purper 1974 and C. danielopoli Purper 1979. They differ from the species studied here in the outline of the posteroventral and anterior margins. The median sulcus in Cytheridella sp. 1 seems to be wider than in the above mentioned species. 


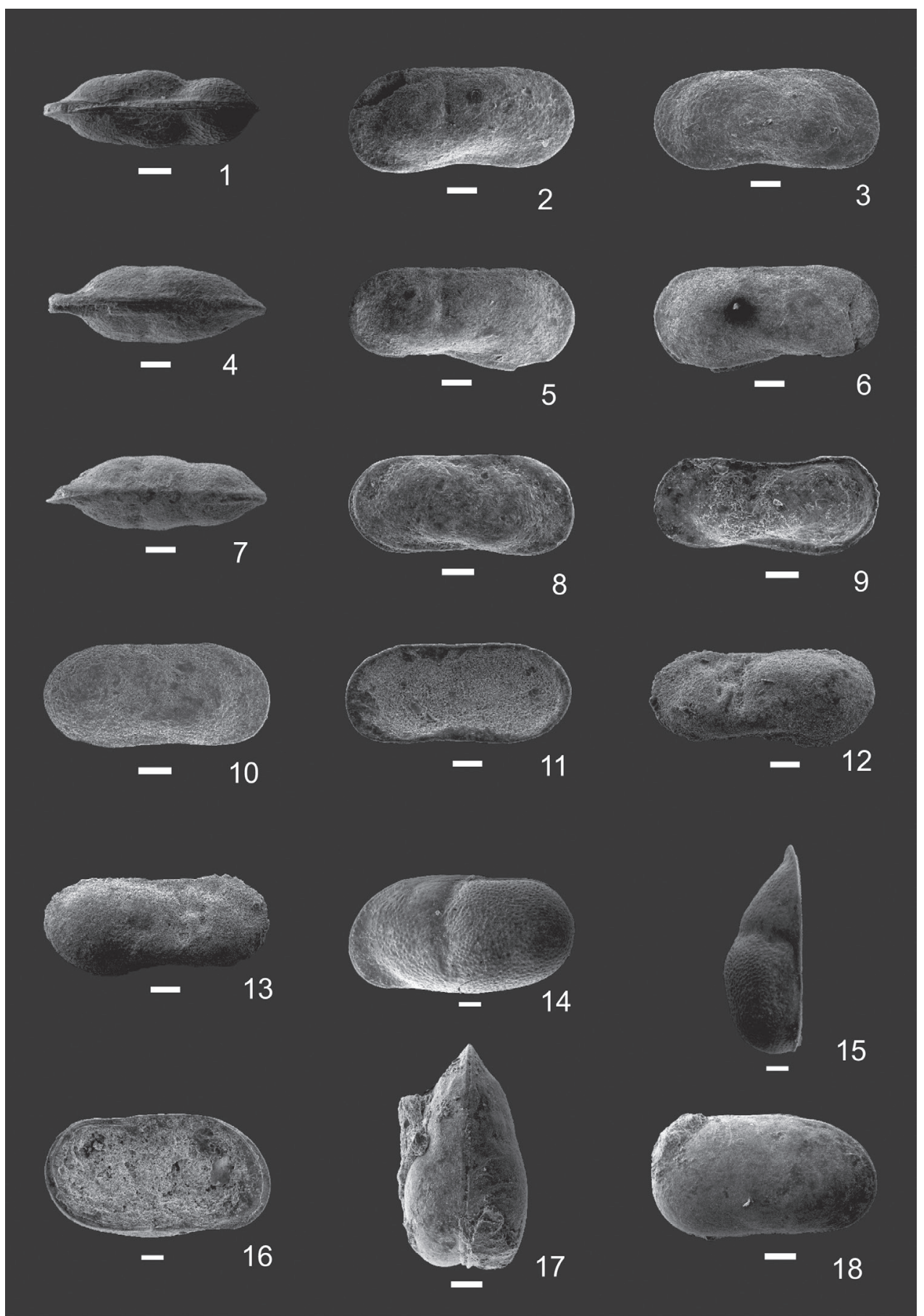

Figure 5 - 1 Limnocythere mandubi sp. nov. (ULVG 11519, C), ventral view; 2-9 Limnocythere katu sp. nov., 2. Left lateral view (ULVG 11522, female C); 3. Right lateral view; 4. Dorsal view; 5. Left lateral view (ULVG 11523, male C); 6. Right lateral view; 7. Dorsal view; 8. Right lateral view (ULVG 11524, A-1 C); 9. Internal view (ULVG 11535, male A-1 RV); 10-11 Limnocythere sp. 1 (ULVG 11525, RV), 10. External view; 11. Internal view. 12-13 Limnocythere? sp. (ULVG 11526, CC), 12. Left lateral view; 13. Right lateral view; 14-16 Cytheridella sp. 1 (ULVG 11527, LV), 14. External view; 15. Dorsal view; 16. Internal view. 17-18 Cytheridella sp. 2 (ULVG 11528, C), 17. Dorsal view; 18. Right lateral view. Scale $=100 \mu$. 
Cytheridella sp. 2

Figs. 5.17-18

Figured specimen: ULVG 11528, C, 1: $0.72 \mathrm{~mm}$, h: $0.42 \mathrm{~mm}$, w: $0.5 \mathrm{~mm}$.

Origin: sample $22.4 \mathrm{~m}$.

Remarks: Cytheridella sp. 2 is considered to be different from Cytheridella sp. 1 due to the smooth surface, outline and depth of the median sulcus. However, the authors are not sure of the adulthood of the specimen here studied.

\section{ON THE PREVIOUS OCCURRENCES OF THE GENERA IN SOUTH AMERICA}

In some Ostracoda (mainly Cypridocopina) the identification, even at generic level, might be hampered when fossils are preserved as closed carapaces or filled valves because the internal characters are not visible. In this work, in an attempt to overcome this restraint, the fossil record of nonmarine ostracods (except the Quaternary one) in South America was also taken into account. This reasoning is based on the assumption that Paleogene non-marine ostracods followed a pattern similar to that of the living ones, i.e., approximately $90 \%$ of species and $60 \%$ of genera restricted to certain zoogeographical regions (Martens et al. 2008).

In South America, data from Cenozoic fossil non-marine ostracods are scarce. The study on the Oligocene Nirihuau Formation (Argentina) by BertelsPsotka and Cusminsky (1999) constitutes one of the few published. In Brazil, they are mostly restricted to Neogene deposits of Solimões Formation. Both Nirihuau and Solimões assemblages present low similarity to the ones in the Tremembé Formation. The only genus shared by the latter and Solimões is Cytheridella, a widely distributed taxon, whose fossil occurrence extends up to Europe (Purper 1974, Monostori 1993). The living species C. boldi Purper 1974, for instance, has also been recorded by Bold (1986) in the Siquire Formation (Neogene, Venezuela).
Limnocythere is widespread in most tropical and subtropical regions. Its Paleogene/Neogene record in South America is represented by three undescribed species from El Carrizo Formation (Musacchio and Moroni 1983), Argentina. The remaining genera (Eucypris, Herpetocypris, Potamocypris, Heterocypris and Strandesia) despite having previous living occurrences in South America, are registered as fossils for the first time in the present study.

\section{PALEOLIMNOLOGICAL INTERPRETATION BASED ON OSTRACOD OCCURRENCES AND PRESERVATION}

Considering that water volume in lakes depends mainly on river inputs and precipitation-evaporation balance, lacustrine sedimentation and biota are strongly influenced by climate. Both taxonomic and non-taxonomic approaches might be adopted in ostracod-based paleolimnology, with the due adjustment to the intrinsic characteristics of nonmarine environments (De Deckker 1988).

The filling of the Taubaté Basin began in the Paleocene and its depositional settings range from lacustrine to fluvial, as demonstrated by sedimentology. The shales correspond to deeper phases, while the argillites, to shallower ones. The alternation of sandstones and argillites in the central portion of the basin was interpreted as lacustrine turbidites (Riccomini et al. 2004). The Tremembé Formation was deposited during the Oligocene in a period of tectonic quiescence which resulted in the accumulation of shales rich in organic matter (Cognè et al. 2013).

Besides sedimentology, the richness and abundance of ostracod assemblages are also indicative of environmental changes in the paleolake Tremenbé. Though paleoelimnologic reconstructions are biased due to poor taxonomy, some remarks are made based on evidences from ostracodes. In an upward analysis of the core, it is possible to distinguish three distinct assemblages 
characterized by the following associations: Herpetocypris-Cytheridella, Limnocythere-Cypretta and Potamocypris-Heterocypris. It must be noted, however, that the samples are unevenly distributed along the core. Probably, a higher sampling resolution in the upper part would increase diversity and abundance improving the paleoecological interpretations (see Fig. 2).

The lower assemblage $(87-79.5 \mathrm{~m})$ is composed by three species, being Herpetocypris sp. 1 very abundant, while Cytheridella sp. 1 and Limnocythere? sp., are represented mainly by scarce and poorly preserved specimens. The middle assemblage $(78.3-57 \mathrm{~m})$ is the richest one, with: Eucypris sp. 1, Heterocypris sp. 1, Herpetocypris sp. 1, Limnocythere sp. 1 and Cypretta sp. Moreover, it is in this assemblage that the two new species proposed occur: Limnocythere mandubi sp. nov. and L. katu sp. nov. The base of the upper assemblage (sample 58.4-59.0 m) is composed mainly of Heterocypris sp. 2, followed by Eucypris sp. 2. The last sample is characterized by the occurrence of Strandesia sp., Cytheridella sp. 2 and Herpetocypris sp. 3 and by the striking dominance of Potamocypris sp. The decrease in richness of this assemblage is interpreted as a phase of shallowing and reduction in the biotopes.

Occurrences of Limnocythere had been tentatively associated to bathymetry, granulometry and/or compactation of the substrate (e.g. Martens and Tudorancea 1991). Recent studies, however, recommend a reassessment of the paleoenvironmental significance of the genus due to precarious autoecologic knowledge (Ramón-Mercau et al. 2014). In the Tremembé Formation the highest abundance of Limnocythere corresponds to argillite and shale deposits (71.5-70 m), which according to Riccomini et al. (2004) corresponds to a deep lake phase. Abundance and richness in water bodies might also be influenced by vegetation. The living species Cypretta vivacis Würdig and Pinto, 1993 has a swimming habit and lives associated to aquatic macrophytes (pleuston). Therefore, it is possible to propose the profuse existence of vegetated biotopes based on the occurrence of Cypretta sp. (73-72 m).

Taphonomy is an important source of nontaxonomic paleolimnological data, as well exemplified by Cohen (1977), in his study in Lake Mobutu, Africa. Among several taphonomic characteristics useful for paleolimnological interpretation, dissolution, articulation of carapaces, color and cup-incup preservation will be discussed below.

Dissolution is common in the interval between 73.2-72 $\mathrm{m}$ affecting specimens of Herpetocypris sp. 1. Carbonate dissolution may result from chemical disequilibrium associated to organic matter input constituting, therefore, another evidence for aquatic macrophyte increase. Supporting this hypothesis is the occurrence of the putative pleustonic Cypretta $\mathrm{sp}$. in the same interval.

Though the ostracods are preserved mostly articulated, some specimens of Limnocythere katu sp. nov. have carapaces slightly open. This pattern, also recorded by Bate (1972), Smith (2000), Williams et al. (2008), Wilkinson et al. (2010), Matzke-Karasz et al. (2013) and Thomé et al. (2014) in fossil non-marine assemblages, is possibly a taphonomic signature of lacustrine deposits.

In relation to the color, specimens of Eucypris sp. 1 and Limnocythere katu sp. nov. in the sample $71.5 \mathrm{~m}$ have black carapaces. In the remaining samples the ostracods are predominantly fawn, except in the top $(20.3 \mathrm{~m})$ where carapaces are white. Although black carapaces are usually associated to dysoxic environments (PalaciosFest et al. 1994), no relation is known between fawn/white carapaces and ambiental conditions. Bertels-Psotka and Cusminsky (1999) make a brief reference to this subject but without remarkable conclusions. Ainsworth et al. (1990) and Kontrovitz et al. (1992), on the other hand, studied the issue in depth, sustaining its potential as an indicator of organic maturity, since color results from input of surrounding mobile hydrocarbons into the ostracod 
carapace. However, it was not possible to make this kind of relation in Taubaté Basin based on the available data.

The cup-in-cup pattern, herein registered in Heterocypris sp. 3, is common in non-marine ostracods (Szeczechura 1971, Carignano and Varela 2011). This biostratinomic signature is an effect of the gentle water movement on carapaces deposited on the shore of lakes and might be considered a paleobathymetric guide. Since Heterocypris sp. 3 occurs in an assemblage associated to the shallowing phase proposed here the potential of the cup-in-cup pattern in paleobathymetry is enhanced by the present study.

The compression, both lateral and dorsoventral, affects specimens in the upper portion of the core. Carapaces not compressed amid are rare, but demonstrate that this feature has no specific relation (since other taxa, such as Cytheridella sp. 2, also present it), or the assemblage is timeaveraged. Additional paleoecological information on Potamocypris is provided by Gutentag and Benson (1962) according to whom the genus is very common in shallow lakes susceptible to evaporative salinity increase. Palynological data by Chagas et al. (2009) support the hypothesis of salinity variations in Tremembé Formation, indicating that its depositional environments ranged from fresh to saline dysoxic waters.

\section{CONCLUSIONS}

The Tremembé Formation holds very rich and moderately preserved ostracod assemblages with huge potential for paleolimnological research. The assemblages, in general, present high richness and abundance, but no relation between their composition and sedimentology is observed. Levels with high abundance have been noticed, and are attributed to ecologic characteristics of the taxon and in lesser degree to preservation bias. Besides the faunal turnover, taphonomic characteristics of the assemblages are also noteworthy and elucidative of the environmental changes which took place in the basin. The analyses of both taxonomic and taphonomic data support an upward shallowing trend model for the studied section. The strong dissimilarity between the Oligocene assemblages from Ñirihuau, El Carrizzo and Tremembé formations suggests a pattern of high endemicity of fossil lacustrine ostracods with analogous in living faunas (sensu Martens et al. 2008).

The genus Limnocythere is well represented in the study, and its first fossil register in Brazil, is a contribution to the paleoenviromental understanding of this important non-marine genus. Other taxa, which could not be studied in detail in this work due to the scarcity or poor preservation of their specimens, demonstrate the importance of the continuity of this research with supplementary material. This study, which represents the first taxonomic and ostracod-based paleoecologic work in Tremembé Formation, reveals the potential of this fossil group for the development of paleolimnological studies in Cenozoic Brazilian deposits.

\section{ACKNOWLEDGMENTS}

CT Bergue thanks Conselho Nacional de Desenvolvimento Científico e Tecnológico (CNPq for the grant $\left.n^{\circ} 474585 / 2013-1\right)$. Koen Martens is thanked for supplying valuable bibliographic references. Ilaria Mazzini, Martin Gross, and an anonymous referee are thanked for the valuable comments to the original version of this manuscript. The authors also wish to express their gratitude to Dr. Hélio Nóbile Diniz who supplied the core from "Projeto Piloto de Recarga Artificial na Bacia do Rio Una, Município de Taubaté" which was supported by Fundação de Amparo a Pesquisa do Estado de São Paulo (FAPESP) grant number 2003/07183-1.

\section{RESUMO}

Os ostracodes não-marinhos oligocênicos da Formação Tremembé (Bacia de Taubaté, Sudeste do Brasil) são pela primeira vez estudados em taxa. $\mathrm{O}$ trabalho 
revelou assembleias ricas compostas, provavelmente, por muitas espécies novas, duas das quais são aqui descritas. As dezesseis espécies de ostracodes registradas são classificadas nos gêneros Cypretta Vávra, Strandesia Stuhlmann, Potamocypris Brady, Heterocypris Claus, Eucypris Vávra, Herpetocypris Brady e Norman, Cytheridella Daday e Limnocythere Brady. Duas novas espécies do último são aqui propostas: L. mandubi sp. nov. e L. katu sp. nov. A sucessão das assembleias de ostracodes presentes ao longo do testemunho estudado apresentam nítidas mudanças na composição, abundância e preservação, e são caracterizadas pelas seguintes associações: Herpetocypris-Cytheridella (base), LimnocythereCypretta (intermediária) e Potamocypris-Heterocypris (topo). Assume-se que estas associações correspondam a diferentes fases ecológicas do paleolago Taubaté, o que está de acordo com anteriores estudos estratigráficos e paleontológicos da bacia. Os resultados deste pioneiro estudo taxonômico e paleoecológico dos ostracodes da Formação Tremembé reforça o potencial destes fósseis para as pesquisas paleolimnológicas nos depósitos Cenozoicos do Brasil.

Palavras-chave: Ostracodes, paleolimnologia, taxonomia, Formação Tremembé.

\section{REFERENCES}

Ainsworth NR, BuRnetT RD AND Kontrovitz M. 1990. Ostracod colour change by thermal alteration, offshore Ireland and western UK. Mar Petrol Geol 7: 288-297.

BATE RH. 1972. Phosphatized ostracods with appendages from the Lower Cretaceous of Brazil. Palaeontology 15(3): 379-393.

Bertels-PsotKA A AND CUSMinsky GC. 1999. Nuevas espécies de ostrácodos de la Formación Nirihuau (Oligoceno) em su área tipo (alredores de San Carlos de Bariloche), província de Rio Negro, República Argentina. Ameghiniana 36: 71-81.

BoLD WA. 1986. Fresh and brackish water Ostracoda from the Neogene of Northern Venezuela. Tulane Stud Geol Paleont 19: 141-157.

BRADY GS. 1886. Notes on Entomostraca collected by A. Haly in Ceylon. J Linnean Soc 19: 293-317.

CARIGNANO AP AND VARELA JA. 2011. Ostrácodos (Crustacea) de la Formación Allen (Cretácico Tardío), Cuenca Neuquina, Argentina. Rev Bras Paleontol 14: 169-178.
Chagas RB, Mendonça-Filho JG, Mendonça JO And MENEZES TR. 2009. Caracterização palinofaciológica de uma sucessão sedimentar oligocênica da Formação Tremembé, Bacia de Taubaté. Rev Bras Paleontol 12: 257-266.

Claus C. 1892. Beiträge zur Kenntnis der SüsswasserOstracoden. Arb Zool Inst Univ Wien, Zool Sta Triëst 10(2): 147-216.

Cognè N, CobBold PR, Riccomini C And Gallagher K. 2013. Tectonic setting of the Taubaté Basin (Southeastern Brazil): Insights from regional seismic profiles and outcrop data. J S Am Earth Sci 42: 194-204.

COHEN AS. 1977. Fossil ostracodes from Lake Mobutu (Lake Albert): palaeoecologic and taphonomic implications. Paleoeco A 18: 271-281.

COHUO-DurÁN S, ELÍAS-GutiÉrREZ M AND KARANOVIC I. 2013. On three new species of Cypretta Vávra, 1895 (Crustacea: Ostracoda) from the Yucatan Peninsula, Mexico. Zootaxa 3636: 501-524.

DE DECKKER P. 1988. An account of the techniques using ostracodes in palaeolimnology in Australia. Palaeogeogr Palaeocl 62: 463-475.

Gross M, RAMOS MIF, CAPORALETTI MAND PILLER WE. 2013. Ostracods (Crustacea) and their palaeoenvironmental implication for the Solimões Formation (Late Miocene; Western Amazonia/Brazil). J S Am Earth Sci 42: 216-241.

Gutentag ED AND Benson RH. 1962. Neogene (PlioPleistocene) fresh water ostracodes from the Central High Plains. K Geol Survey Bull 157: 1-60.

KARANOVIC I. 2005. On the genus Strandesia Stuhlmann, 1888 (Crustacea, Ostracoda, Cypridiadae) with description of Strandesia kimberleyi n. sp. and a key to the extant species of the genus. Contrib Zool 74: 77-95.

KARANOVIC I. 2012. Recent freshwater ostracods of the world. Crustacea, Ostracoda, Podocopida, Heidelberg: Springer, $608 \mathrm{p}$.

Kontrovitz M, AInsworth NR, BurnetT RD AND SLACK JM. 1992. Induced colors in ostracode shells: an experimental study. The University of Kansas Paleontological Contributions 2: 1-10.

LAPRIDA C, DÍAZ A AND RATTO N. 2006. Ostracods (Crustacea) from thermal waters, Southern Altiplano, Argentina. Micropaleontology 52: 177-188.

MARTENS K. 1989. Ovambocythere milani gen. n., spec. n. (Crustacea, Ostracoda), na African limnocytherid reared from dried mud. J Afr Zool 103: 379-388.

MARTENS K AND SAVATENALinton S. 2011. A subjective checklist of the Recent, free-living, non-marine Ostracoda (Crustacea). Zootaxa 2855: 1-79.

Martens K, Schön I, MeISChe C AND Horne D. 2008. Global diversity of ostracods (Ostracoda, Crustacea) in freshwater. Hydrobiologia 595: 185-193.

MARTENS K AND TUdORANCEA C. 1991. Seasonality and spatial distribution of the ostracods of Lake Zwai, Ethiopia (Crustacea: Ostracoda). Freshwater Biol 25: 233-241. 
MatzKe-Karasz R, NeIL JV, SMith RJ, GodThelP H, ARCHER M AND HAND SJ. 2013. Ostracods (Crustacea) with soft part preservation from Miocene cave deposits of the Riversleigh World Heritage Area, NW Queensland, Australia. J Syst Palaeontol 2013: 1-31.

Mezzalira S. 1989. Os fósseis do Estado de São Paulo. São Paulo, IGG, Série Pesquisa, 155 p.

Monostori M. 1993. The genus Cytheridella in the Paleogene of eastern Europe. Rev Esp Micropaleontol 25: 107-112.

MusACCHIO EA AND MORONI AM. 1983. Charophyta y Ostracoda no marinos eoterciários de la Formación El Carrizzo en la provínica de Rio Negro, Argentina. Ameghiniana 20: 21-33.

PALACIOS-FEST MR, COHEN AS AND ANADÓN P. 1994. Use of ostracodes as paleoenvironmental tools in the interpretation of ancient lacustrine records. Rev Esp Palaontol 9: 145-162.

PINTO ID AND SANGUINETTI YT. 1958. Bisulcocypris a new Mesozoic genus and preliminary note about its relation with Metacypris and allied forms. Bol Soc Bras Geol 7: 75-90.

PINTO ID AND SANGUINETTI YT. 1962. A complete revision of the genera Bisulcocypris and Theriosynoecum (Ostracoda) with the world geographical and stratigraphical distribution (including Metacypris, Elpidium, Gomphocythere and Cytheridella). Publicação Especial da Escola de Geologia de Porto Alegre 4: 1-165.

PURPER I. 1974. Cytheridella boldii Purper, sp. nov. (Ostracoda) from Venezuela and a revision of the genus Cytheridella Daday, 1905. An Acad Bras Cienc 46: 635-662.

PURPer I. 1979. Cenozoic ostracodes of the upper Amazon Basin, Brazil. Pesquisas 12: 209-281.

PURPER I AND WÜRDIG-MACIEL NL. 1974. Occurrence of Heterocypris incongruens (Ramdohr), 1808 - Ostracoda - in Rio Grande do Sul, Brazil. Discussion on the allied genera: Cyprinotus, Hemicypris, Homocypris and Eucypris. Pesquisas 3: 69-91.

Ramón-Mercau J, Plastani MS and Laprida C. 2014. A review of the genus Limnocythere (Podocopida: Limnocytehridae) in the Pampean Region (Argentina), with the description of a new species, Limnocythere kusminskyae sp. nov. Zootaxa 3821(1): 26-36.
RAMOS MIF. 2006. Ostracods from the Neogene Solimões Formation (Amazonas, Brazil). J S Am Earth Sci 21: 87-95.

RicCOMINI C, SANT'ANNA LG AND FERRARI AL. 2004 Evolução geológica do Rift Continental Sudeste do Brasil. In: Mantesso-Neto V et al. (Eds), Geologia do Continente Sul-Americano: evolução da obra de Fernando Flávio Marques de Almeida, São Paulo: Ed. Becca, p. 383-405.

SHEPPARD LM AND BATE RH. 1980. Plio-Pleistocene ostracods from the upper Amazon of Colombia and Peru. Palaeontology 23: 97-124.

SMITH RJ. 2000. Morphology and ontogeny of Cretaceous ostracods with preserved appendages from Brazil. Palaeontology 43: 63-98.

SZECZECHURA J. 1971. Fresh-water Ostracoda from the Paleocene of the Nemegt Basin, Gobi Desert, Mongolia. Palaeontol Pol 25: 85-97.

THOMÉ METR, LIMA FILHO MF AND NEUMANN VHML. 2014. Taxonomic studies of non-marine ostracods in the Lower Cretaceous (Aptian-lower Albian) of post-rift sequence from Jatobá and Araripe basins (Northeast Brazil): Stratigraphic implications. Cretaceous Res 48: 153-172.

Wilkinson IP, Wilby PR, Williams M, Siveter DJ, Page AA, LegGitT L AND RILEY DA. 2010. Exceptionally preserved ostracodes from a Middle Miocene palaeolake, California, USA. J. Geol Soc London 167: 817-825.

Williams M, Siveter DJ, ASHWORTh AC, WILBY PR, HorNE DJ, LEWIS AR AND MARCHANT DR. 2008. Exceptionally preserved lacustrine ostracods from the Middle Miocene of Antarctica: implications for high-latitude palaeoenvironment at $77^{\circ}$ South. P Roy Soc Lond B 275: 2449-2454. doi:10.1098/rspb.2008.0396

WÜRDIG NLAND PINTO ID. 1993. A New-fresh water Ostracoda from Southern Brazil. An Acad Bras Cienc 65: 89-99. 